Pak. j. sci. ind. res. Ser. B: biol. sci. 201457 (1) 5-10

\title{
Growth and Yield Response of Sunflower (Helianthus annuus L.) to Sulphur and Boron Application
}

\author{
Muhammad Tahir, Shahzad Ahmed Shah, Muhammad Ayub, Asif Tanveer and \\ Haseeb-ur- Rehman* \\ Department of Agronomy, University of Agriculture, Faisalabad, Pakistan
}

(received February 7, 2013; revised July 31, 2013; accepted September 27, 2013)

\begin{abstract}
An experiment was conducted to study the growth and yield response of sunflower to sulphur and boron application. Sulphur (control, $15,30 \mathrm{~kg} / \mathrm{ha}$ ) and foliar sprays of $1 \%$ boron solution (control, spray at 4 week after emergence, 20 days after first spray, at 4 weeks after germination +20 days after first spray) was applied in soil. The results showed significant increase of all growth and yield parameters by varying levels of sulphur and boron application. Application of $30 \mathrm{~kg}$ sulphur/ha enhanced stem diameter $(1.99 \mathrm{~cm})$, number of achene per head $(765.75)$ and oil content $(36.42 \%)$. In case of combined use of sulphur and boron application, maximum plant height $(171 \mathrm{~cm})$, head diameter $(20.71 \mathrm{~cm}), 1000$-achene weight (54.56 g), biological yield (16.49 t/ha) and achene yield (3.99 t/ha) was recorded by the application of 2 sprays of boron solution (1\%) at 4 weeks after germination and reproductive stage.
\end{abstract}

Keywords: sunflower, sulphur, boron, growth, yield

\section{Introduction}

The economy of Pakistan is agriculture based, accounting for over $21 \%$ of GDP, hence, it remains by far the largest employer. Among the oil seed crops, sunflower (Helianthus annuus L.) belonging to the family (Compositae) plays a major role in vegetable oil industry in the whole world. The protein content of sunflower cake ranges from 20-40\% (Gandhi et al., 2008). In Pakistan, sunflower is a newly introduced oil seed crop. The area under sunflower crop in 2011-12 was 877 thousand acres with 473 thousand tonne achene yield (MINFAL, 2011).

Micronutrient deficiency can greatly disturb crop production which ultimately affects human and animal health (Malakouti, 2007). Among them sulphur is essential for growth and development of all crops. Plants absorb sulphur through roots in the form of sulphate. Sulphur is involved in the formation of vitamins, grains, oils, fruits and vegetables. Regarding chemical composition of seed, sulphur is very important for increasing the oil percentage in seeds (Welch, 2003). Boron is an essential element required in micro amount but producing a macro impact on plant growth and development. Boron is involved in numerous important processes, including protein synthesis, transport of sugar, respiration, RNA, plant hormones and carbohydrate metabolism, flowering

*Author for correspondence; E-mail: haseeb_khar@hotmail.com and fruiting (Tariq and Mott, 2007; Havlin et al., 2005) Moreover, functions of boron are related to cell wall synthesis, lignification and cell wall structure by crosslinking of cell wall polysaccharides as well as the structural integrity of bio membranes (Tanaka and Fujiwara, 2008). The requirement for boron fertilisation is rising because of higher crop yield and reduced quantity of organic matter and severe boron removal by crops. Boron is critical for the process of cell differentiation at all growing tips of plants (meristems), where cell division is active (Adiloglu and Adiloglu, 2006). Deformed flowering is a common symptom of boron deficiency. Many plants may respond by reduced flowering and improper pollination as well as thickened, curled, wilted and chlorotic new growth. On the basis of current knowledge about sulphur and boron evaluations, a field experiment was arranged to study the combined effect of these nutrients to assess the response of various growth and yield attributes of hybrid sunflower under Faisalabad, Pakistan conditions.

\section{Materials and Methods}

An experiment was conducted at the research area, Department of Agronomy, University of Agriculture, Faisalabad, to determine the effect of sulphur and boron on growth, yield and quality of hybrid sunflower. The experiment was laid out in randomised complete block design with factorial arrangement having three replica- 
tions with a net plot size of $4.5 \mathrm{~m} \times 7.0 \mathrm{~m}$. Before sowing of crop a portion of the prepared soil samples was used to analyse its various physicochemical properties. Soil was sandy clay loam (65\% sand $16 \%$ silt and 19\% clay). Soil pH (7.8) and electrical conductivity $(1.3 \mathrm{dS} / \mathrm{m})$ was measured in saturation extract using digital EC meter. Organic matter content $(0.79 \%)$, total $\mathrm{N}(0.047 \mathrm{ppm})$, available phosphorus $(8.75 \mathrm{ppm})$, and available potassium (165 ppm) was recorded. Boron $(0.39 \mathrm{ppm})$ and no sulphur were found.

The experiment comprised of soil application of sulphur (control, $15,30 \mathrm{~kg} / \mathrm{ha}$ ) and foliar sprays of $1 \%$ boron solution (control, spray at 4 week after emergence, 20 days after first spray, at 4 weeks after germination +20 days after first spray). The seedbed was prepared by cultivating the field for 2 times with tractor-mounted cultivator each followed by planking. Sunflower hybrid, Huysun-33 was sown on ridges in August 6, 2009 with the help of dibbler keeping $\mathrm{R} \times \mathrm{R}$ and $\mathrm{P} \times \mathrm{P}$ distances of $75 \mathrm{~cm}$ and $25 \mathrm{~cm}$, respectively. Seed rate of $6 \mathrm{~kg} / \mathrm{ha}$ was used. Sulphur and boron were applied as per treatment. Recommended doses of nitrogen and phosphorus were applied to all plots. DAP and urea was applied as a source of phosphorus and nitrogen. All recommended phosphorus $(100 \mathrm{~kg} / \mathrm{ha})$ was applied at sowing time as a basal dose, while, nitrogen was applied in three splits i.e., $1^{\text {st }}$ at sowing time, $2^{\text {nd }}$ with first irrigation and $3^{\text {rd }}$ with second irrigation. Sulphur was applied at sowing stage and boron was applied as foliar spray at vegetative and reproductive stages of the crop using available resources of elemental sulphur and boric acid. All other agronomic practices, except treatments under study, were kept normal and uniform for all treatments. All the plant protection measures (weeds and insects pests' control) were taken according to the recommendation for sunflower crop. Crop was harvested manually at physiological maturity. Separate threshing was done for each experimental unit to obtain data regarding achene yield for each treatment. Plant protection measures were adopted to keep crop free of weeds, insect pests and diseases.

Ten plants were selected at random from each experimental unit. Height of those selected plants was measured and then averaged. Stem girth was measured of all ten plants with the help of Vernier caliper from top, mid and bottom of the plants and then averaged to calculate the diameter. The head diameter of ten randomly particular plants was measured and finally averaged. Ten heads were selected randomly from each treatment dried and threshed. Achene were counted and averaged to calculate the number of achenes per head. Ten samples of 1000 seeds were taken randomly from achene lot of each experimental unit. They were weighed and averaged to measure the 1000 achenes weight. After harvest at physiological maturity, the heads were separated from the plants, sun dried, threshed and the seed yield per plot was recorded with weighing balance. The achenes yield was converted into tonnes per hectare. Weight of sun dried plants (including heads) was taken on per plot basis and then transformed into tonnes per hectare to find out the biological yield. Seed samples were taken randomly from each subplot and oil contents were determined by AOAC (1990). Protein content of sunflower seed samples collected from each subplot were determined by the micro Kjeldahl method. One gram of each sample was transferred to Kjeldahl flask; a digestion tablet was added to $5 \mathrm{~mL}$ of concentrated $\mathrm{H}_{2} \mathrm{SO}_{4}$ and contents mixed thoroughly. The flask was placed on the digestion assembly; heater and exhaust fan were turned on. The digestion was continued with occasional shaking of flask. When the solution became clear and all the organic matter had been oxidised, the digestion was continued for another $30 \mathrm{~min}$.

\section{Results and Discussion}

Plant height at maturity $(\mathbf{c m})$. The data presented in Table 1 revealed that interaction between boron and sulphur application, being highly significant, proved a combination of $30 \mathrm{~kg} / \mathrm{ha}$ sulphur and a single spray at 4 weeks after germination of $1 \%$ boron solution, to give the highest plant height $(171 \mathrm{~cm})$ at maturity. The effect of boron application was non-significant when no sulphur was applied. This might be attributed to the positive interaction between sulphur and boron. Sulphur is needed for chlorophyll formation and boron for increased cell division, which enhanced the intermodal distance and finally plant height. Results obtained in this study regarding plant height at maturity, are in line with Reddy and Chaturvedi (2009) and Sarker et al. (2002), who also reported the increase in plant height due to boron $\times$ sulphur application.

Stem diameter $(\mathbf{c m})$. The potential growth of sunflower is determined from its vigorously growing stem. Significant differences in stem diameter of sunflower were observed in boron and sulphur level, however, their 
Table 1. Growth and yield response of sunflower (Helianthus annuus L.) to sulphur and boron application

\begin{tabular}{|c|c|c|c|c|c|c|c|c|c|}
\hline Treatments & $\begin{array}{l}\text { Plant } \\
\text { height } \\
(\mathrm{cm})\end{array}$ & $\begin{array}{l}\text { Stem } \\
\text { diameter } \\
(\mathrm{cm})\end{array}$ & $\begin{array}{l}\text { Head } \\
\text { diameter } \\
(\mathrm{cm})\end{array}$ & $\begin{array}{l}\text { Number of } \\
\text { achene } \\
\text { per head }\end{array}$ & $\begin{array}{l}1000- \\
\text { achene } \\
\text { weight } \\
\text { (g) }\end{array}$ & $\begin{array}{l}\text { Achene } \\
\text { yield } \\
(\mathrm{t} / \mathrm{ha})\end{array}$ & $\begin{array}{l}\text { Biological } \\
\text { yield } \\
(\mathrm{t} / \mathrm{ha})\end{array}$ & $\begin{array}{l}\text { Oil } \\
\text { contents } \\
(\%)\end{array}$ & $\begin{array}{l}\text { Protein } \\
\text { contents } \\
(\%)\end{array}$ \\
\hline $\mathrm{S}_{0}(0 \mathrm{~kg} / \mathrm{ha})$ & $133.92 \mathrm{C}$ & $1.47 \mathrm{C}$ & $13.92 \mathrm{C}$ & $664.58 \mathrm{C}$ & $41.76 \mathrm{C}$ & $3.07 \mathrm{C}$ & $13.37 \mathrm{C}$ & $32.13 \mathrm{C}$ & 15.70 \\
\hline $\mathrm{S}_{1}(15 \mathrm{~kg} / \mathrm{ha})$ & $147.92 \mathrm{~B}$ & $1.64 \mathrm{~B}$ & $18.65 \mathrm{~B}$ & $726.58 \mathrm{~B}$ & $44.35 \mathrm{~B}$ & $3.25 \mathrm{~B}$ & $14.65 \mathrm{~B}$ & $34.64 \mathrm{~B}$ & 16.00 \\
\hline $\mathrm{S}_{2}(30 \mathrm{~kg} / \mathrm{ha})$ & $167.50 \mathrm{~A}$ & $1.99 \mathrm{~A}$ & $19.95 \mathrm{~A}$ & $765.75 \mathrm{~A}$ & $53.82 \mathrm{~A}$ & $3.96 \mathrm{~A}$ & $16.46 \mathrm{~A}$ & $36.42 \mathrm{~A}$ & 14.76 \\
\hline $\begin{array}{l}\text { LSD value } \\
\text { (for } \mathrm{S} \text { at } 5 \% \text { ) }\end{array}$ & 6.39 & 0.14 & 1.46 & 4.99 & 3.88 & 0.28 & 1.23 & 2.86 & NS \\
\hline $\begin{array}{l}B_{0} \text { (No spray) } \\
B_{1}(1 \text { spray at four } \\
\text { weeks after }\end{array}$ & 147.44 & 1.63 & 17.44 & $700.67 \mathrm{D}$ & $46.28 \mathrm{~B}$ & 3.39 & 14.79 & $33.43 \mathrm{C}$ & 15.17 \\
\hline germination) & 150.78 & 1.71 & 17.75 & $712.78 \mathrm{BC}$ & 47.12 & 3.41 & 14.81 & $34.65 \mathrm{AB}$ & 15.53 \\
\hline $\begin{array}{l}\mathrm{B}_{2}(1 \text { spray at } \\
\text { reproductive stage })\end{array}$ & 152.11 & 1.76 & 17.18 & $724.11 \mathrm{~B}$ & $46.49 \mathrm{~B}$ & 3.43 & 14.83 & $34.21 \mathrm{BC}$ & 15.42 \\
\hline $\begin{array}{l}\mathrm{B}_{3}\left(\mathrm{~B}_{1}+\mathrm{B}_{2}\right) \\
\mathrm{LSD} \text { value } \\
\text { (for } \mathrm{B} \text { at } 5 \%\end{array}$ & 148.78 & 1.69 & 17.66 & $738.33 \mathrm{~A}$ & $46.69 \mathrm{AB}$ & 3.47 & 14.87 & $35.30 \mathrm{~A}$ & 15.83 \\
\hline probability level) & NS & NS & NS & 6.65 & 0.38 & NS & NS & 3.82 & NS \\
\hline $\mathrm{S}_{0} \mathrm{~B}_{0}$ & $133.33 \mathrm{e}$ & 1.41 & $13.77 \mathrm{e}$ & 638.33 & $40.66 \mathrm{~b}$ & $3.05 \mathrm{f}$ & $13.35 \mathrm{f}$ & 30.67 & $13.57 \mathrm{~h}$ \\
\hline $\mathrm{S}_{1} \mathrm{~B}_{0}$ & $148.33 \mathrm{c}$ & 1.60 & $18.92 \mathrm{c}$ & 715.00 & $44.31 \mathrm{~b}$ & $3.19 \mathrm{e}$ & $14.59 \mathrm{e}$ & 33.63 & $16.44 \mathrm{~b}$ \\
\hline $\mathrm{S}_{2} \mathrm{~B}_{2}$ & $160.67 \mathrm{~b}$ & 1.90 & $19.62 \mathrm{~b}$ & 748.67 & $53.87 \mathrm{a}$ & $3.92 \mathrm{~b}$ & $16.42 \mathrm{~b}$ & 36.00 & $15.51 \mathrm{e}$ \\
\hline $\mathrm{S}_{0} \mathrm{~B}_{1}$ & $133.33 \mathrm{e}$ & 1.46 & $13.91 \mathrm{e}$ & 657.67 & $42.47 \mathrm{~b}$ & $3.06 \mathrm{f}$ & $13.35 \mathrm{f}$ & 32.17 & $15.49 \mathrm{e}$ \\
\hline $\mathrm{S}_{1} \mathrm{~B}_{1}$ & $148.00 \mathrm{c}$ & 1.65 & $18.74 \mathrm{~cd}$ & 721.00 & $44.70 \mathrm{~b}$ & $3.21 \mathrm{de}$ & $14.59 \mathrm{e}$ & 34.70 & $16.18 \mathrm{bc}$ \\
\hline $\mathrm{S}_{2} \mathrm{~B}_{1}$ & $171.00 \mathrm{a}$ & 2.01 & $20.61 \mathrm{a}$ & 759.67 & $54.20 \mathrm{a}$ & $3.95 \mathrm{ab}$ & $16.42 \mathrm{~b}$ & 37.08 & $14.93 \mathrm{f}$ \\
\hline $\mathrm{S}_{0} \mathrm{~B}_{2}$ & $135.33 \mathrm{e}$ & 1.49 & $14.00 \mathrm{e}$ & 669.00 & $42.60 \mathrm{~b}$ & $3.07 \mathrm{f}$ & $13.37 \mathrm{f}$ & 32.70 & $16.06 \mathrm{bcd}$ \\
\hline $\mathrm{S}_{1} \mathrm{~B}_{2}$ & $153.00 \mathrm{c}$ & 1.69 & $18.67 \mathrm{~cd}$ & 732.00 & $44.20 \mathrm{~b}$ & $3.25 \mathrm{~d}$ & $14.65 \mathrm{~d}$ & 34.77 & $15.78 \mathrm{cde}$ \\
\hline $\mathrm{S}_{2} \mathrm{~B}_{2}$ & $168.00 \mathrm{a}$ & 2.09 & $18.85 \mathrm{c}$ & 771.33 & $52.67 \mathrm{a}$ & $3.97 \mathrm{a}$ & $16.47 \mathrm{a}$ & 35.15 & $14.43 \mathrm{~g}$ \\
\hline $\mathrm{S}_{0} \mathrm{~B}_{3}$ & $133.67 \mathrm{e}$ & 1.51 & $14.00 \mathrm{e}$ & 693.33 & $41.29 \mathrm{~b}$ & $3.08 \mathrm{f}$ & $13.38 \mathrm{f}$ & 32.97 & $17.70 \mathrm{a}$ \\
\hline $\mathrm{S}_{1} \mathrm{~B}_{3}$ & $142.33 \mathrm{~d}$ & 1.62 & $18.26 \mathrm{~d}$ & 738.33 & $44.20 \mathrm{~b}$ & $3.33 \mathrm{c}$ & $14.73 \mathrm{c}$ & 35.47 & $15.62 \mathrm{de}$ \\
\hline $\begin{array}{l}\mathrm{S}_{2} \mathrm{~B}_{3} \\
\mathrm{LSD} \text { value (for } \mathrm{S} \times \mathrm{B}\end{array}$ & $170.33 \mathrm{a}$ & 1.95 & $20.71 \mathrm{a}$ & 783.33 & $54.56 \mathrm{a}$ & $3.99 \mathrm{a}$ & $16.49 \mathrm{a}$ & 37.46 & $14.18 \mathrm{~g}$ \\
\hline $5 \%$ probability level) & 4.16 & NS & 5.83 & NS & 7.13 & 1.03 & 2.2 & NS & 0.56 \\
\hline
\end{tabular}

Source of variation

Analysis of variance

\begin{tabular}{lllllllllll}
\hline & D.F & P.H & S.D & H.D & NAH & TAW & AY & BY & OC & PC \\
\hline Replication & 2 & 95.361 & 0.00610 & 0.2317 & 66.0 & 0.629 & 0.001 & 0.0011 & 2.904 & 0.002 \\
Sulphur (S) & 2 & $3414.694^{* *}$ & $0.840^{* *}$ & $120.811^{* *}$ & $31225.4^{* *}$ & $484.105^{* *}$ & $2.673^{* *}$ & $28.985^{* *}$ & $55.861^{* *}$ & $5.044^{* *}$ \\
Boron (B) & 3 & NS & NS & NS & $2324.2^{* *}$ & $1.162^{*}$ & NS & NS & $5.521^{* *}$ & $0.677^{* *}$ \\
Sulphur x Boron & 6 & $44.250^{* *}$ & NS & $1.004^{* *}$ & NS & $1.833^{* *}$ & $0.002^{*}$ & $0.002^{*}$ & NS & $4.746^{* *}$ \\
Error & 22 & 9.755 & 0.003 & 0.086 & 71.1 & 0.302 & 0.000 & 0.0006 & 0.932 & 0.080 \\
Total & 35 & & & & & & & & &
\end{tabular}

* = significance at $\mathrm{P} \leq 0.05$ level of probability; abbreviations: $\mathrm{D} . \mathrm{f}=$ degree of Freedom, $\mathrm{PH}=$ plant height, $\mathrm{SD}=$ stem diameter, $\mathrm{HD}=$ head diameter, $\mathrm{NAH}=$ number of achenes per head, $\mathrm{TAW}=1000$-achene weight, $\mathrm{AY}=$ achene yield, $\mathrm{BY}=$ biological yield, $\mathrm{OC}=$ oil contents and $\mathrm{PC}=$ protein contents. 
interactions were non-significant for the parameter under discussion. Maximum stem diameter $(1.99 \mathrm{~cm})$ of sunflower was obtained from plots, where, sulphur was applied at $30 \mathrm{~kg} / \mathrm{ha}$ and minimum $(1.47 \mathrm{~cm})$ stem diameter was produced, where, no sulphur was applied. Among boron levels, single spray at reproductive stage produced maximum stem diameter of $1.76 \mathrm{~cm}$, which was statistically at par with single sprays at 4 weeks after germination. Minimum $(1.63 \mathrm{~cm})$ stem diameter was produced, where, no spray of boron was applied, which, however, remained statistically similar to two sprays of boron at vegetative and reproductive stages $\left(\mathrm{B}_{3}\right)$. The improvement in stem diameter might be due to application of boron and sulphur, which enhanced the stem diameter of sunflower. These results are in line with the results of Tomar et al. (1997), who also reported increase in stem diameter with application of boron.

Head diameter $(\mathbf{c m})$. The production potential of sunflower crop is determined by the size of its head, which is an important yield contributing factor. The data shows that head diameter was significantly, affected by sulphur and boron seperately and their interaction. The head diameter of sunflower was highest $(19.95 \mathrm{~cm})$, when $30 \mathrm{~kg} / \mathrm{ha}$ of sulphur was applied and it was lowest $(13.92 \mathrm{~cm})$, when no sulphur fertiliser was applied. Whereas, in case of boron, single spray at 4 weeks after germination proved to give the maximum head diameter $(20.61 \mathrm{~cm})$, which was statistically similar with two sprays at vegetative and reproductive stages. The minimum head diameter was recorded from single spray at reproductive stage and was statistically at par with control, where, no boron was applied $\left(\mathrm{B}_{0}\right)$. The interaction between boron and sulphur application, proved a combination of $30 \mathrm{~kg} / \mathrm{ha}$ sulphur and a single spray of $1 \%$ boron solution at 4 weeks after germination to give the highest head diameter $(20.71 \mathrm{~cm})$ and the lowest head diameter was noted $(13.77 \mathrm{~cm})$, where, neither sulphur nor boron treatment was applied. This might be due to application of $\mathrm{B}$, which enhanced pollen viability flower, fruit set, hormone formation and increased the stem diameter. The results of present study regarding the head diameter were at par with the results reported by Oyinlola (2007), who found that the head diameter of sunflower increases with boron application.

Number of achenes per head. Number of achenes per head contributes significantly, towards the final yield of the crop and it also determines the yield potential of the sunflower crop. Significant differences were observed in number of achenes per head among boron levels and sulphur levels, while, non-significant differences were found in boron and sulphur interactions. The minimum number of achenes was recorded from control, where, no sulphur was applied. The number of achenes increased significantly, with each increase in sulphur level. The maximum number of achenes (765.75) was recorded with sulphur application of $30 \mathrm{~kg} / \mathrm{ha}$. As far as boron levels are concerned, two sprays, one at vegetative and other at reproductive stage, were found best, which produced maximum number of achenes (738.33) as compared to minimum in control (700.67). The improvement in achenes per head might be due to more head diameter and proper and timely application of sulphur and boron. These results are in line with those of Sarkar et al. (1999), who reported increase in number of achenes per head with the application of boron and sulphur.

1000-achene weight $(\mathrm{g})$. Stout and sturdy achenes are a sign of high yield and quality produce, which, contributes significantly, towards its final yield. 1000achene weight was greatly influenced by sulphur and boron nutrition. Significant differences were observed among sulphur levels, boron levels and sulphur $\times$ boron interactions. In case of sulphur doses, $30 \mathrm{~kg} / \mathrm{ha}$ elemental sulphur produced maximum thousand achene weight $(53.82 \mathrm{~g})$ and on the contrary, control produced minimum (41.76 g). Single spray of $1 \%$ boron solution at 4 weeks after germination produced maximum thousand achene weight $(47.12 \mathrm{~g})$. The interaction between sulphur and boron was also significant. Application of sulphur at the rate of $30 \mathrm{~kg} / \mathrm{ha}$ with two sprays of boron on both vegetative and reproductive stages, produced maximum thousand achene weight (54.56 g), which was statistically at par with single spray of boron at 4 weeks after germination and application of sulphur at $0 \mathrm{~kg} / \mathrm{ha}$ with no spray of boron produced the minimum thousand achene weight ( $40.66 \mathrm{~g}$ ). Improvement in achene weight may be due to maximum diameter and number of achenes per head. Combined application of sulphur and boron also increased the 1000-achene weight. These results are also in line with those of Sarkar et al. (2002), who reported an improvement in 1000-achene weight with application of boron and sulphur.

Achene yield (t/ha). Achene yield is a function of integrated effects of the various yield components and any variation in them is liable to bring about variation in yield. Significant, differences in achene yield were observed in sulphur levels, boron levels and sulphur $x$ boron interaction. The data indicated that sulphur at 
the rate of $30 \mathrm{~kg} / \mathrm{ha}$ produced highest (3.96 t/ha) achene yield as compared to control, which, produced lowest (3.07 t/ha) achene yield. In case of boron, two sprays (at both, vegetative and reproductive stages) produced maximum achene yield ( $3.47 \mathrm{t} / \mathrm{ha})$ and control produced the minimum (3.39 $\mathrm{t} / \mathrm{ha})$. The interaction between sulphur and boron application for achene yield was significant. The maximum yield (3.99 t/ha) was obtained when sulphur was applied at $30 \mathrm{~kg} / \mathrm{ha}$ with two sprays of boron on both, vegetative and reproductive stages and minimum (3.05 t/ha) was obtained without boron and sulphur application. Improvement in achene yield is due to maximum head diameter, number of achene per head and 1000-achenes weight. Similar results were also reported by Sarker et al. (2002) and Salim et al. (1997), who reported that achene yield can also be increased with application of boron and sulphur in combination.

Biological yield (t/ha). Biological yield is the total biomass produced by a crop by utilising the resources available at the time. Significant differences in biological yield were observed in sulphur levels, boron levels and sulphur $\times$ boron interaction. Maximum biological yield (16.46 t/ha) was obtained with sulphur at the rate of $30 \mathrm{~kg} / \mathrm{ha}$, as compared to control, which produced lowest (13.37 t/ha) biological yield. In case of boron, two sprays (at both, vegetative and reproductive stages) produced maximum biological yield of $14.87 \mathrm{t} / \mathrm{ha}$ and control produced $14.79 \mathrm{t} / \mathrm{ha}$. In case of sulphur and boron interaction, significantly, maximum yield (16.49 t/ha) was recorded, where, sulphur at the rate of $30 \mathrm{~kg} / \mathrm{ha}$ with two sprays of boron at both, vegetative and reproductive stages were applied. Minimum (13.35 $\mathrm{t} / \mathrm{ha}$ ) was obtained at $0 \mathrm{~kg}$ sulphur with no spray of boron. Increase in biological yield is attributed to proper utilisation of boron. Results of this study are also in line with those of Sarker et al. (2002), who also reported increase in biological yield due to sulphur and boron application.

Achene oil content (\%). A crop rich in oil contents is the ultimate goal of the growers. Significant differences were observed in oil content of achenes among boron and sulphur levels, while, non-significant differences were found in boron and sulphur interaction. Maximum achene oil content (36.42\%) was obtained from sulphur applied at the rate of $30 \mathrm{~kg} / \mathrm{ha}$ and minimum achene oil content (32.13\%) was found, where, no sulphur was applied. As far as boron levels are concerned, two sprays, one at vegetative and another at reproductive stage, were found best, which produced maximum achene oil content $(35.30 \%)$ as compared to minimum in control (33.43\%). Boron along with sulphur application increased the oil contents because sulphur is constituent of several amino acids, which are essential for protein production. These results are in line with those of Diggs et al. (1992), who reported an increase in oil content of seed with the increase in sulphur dose.

Achene protein content (\%). Protein content in seeds indicates the quality and dietary value of the seeds. The data shows that significant differences were observed in protein content among sulphur levels, boron levels and their interaction. The data regarding the role of sulphur in promoting the protein content reflected that most efficient sulphur dose was $15 \mathrm{~kg} / \mathrm{ha}$, which produced highest $(16 \%)$ protein content and on the other hand a high dose $(30 \mathrm{~kg} / \mathrm{ha})$ of sulphur found to be producing lowest $(14.76 \%)$ protein content. In case of boron, two sprays, one at vegetative and another at reproductive stage, were found best, which produced maximum $(15.83 \%)$ protein content and minimum $(15.17 \%)$ protein contents were noted in control. Whereas, in case of interaction of sulphur and boron, the best treatment combination was $\mathrm{S}_{0} \mathrm{~kg} / \mathrm{ha}$ with two sprays of boron; one at vegetative and another at reproductive stage and minimum protein content was recorded, where, $\mathrm{S}_{0} \mathrm{~kg} / \mathrm{ha}$ and no boron were sprayed.

\section{Conclusion}

From results of experiments it can be concluded that two sprays of boron solution (1\%) first spray at 4 weeks after emergence and second 20 days after first spray in combination with S (30 kg/ha), significantly, increased head diameter (20.71), 1000-achene weight (54.56), achene yield (3.99 t/ha) and biological yield (16.49 t/ha) as compared to control.

\section{References}

AOAC, 1990. Official Methods of Analysis of Association of Official Analytical Chemists, $15^{\text {th }}$ edition, Association of Official Analytical Chemists, Washington, DC., USA.

Adiloglu, A., Adiloglu, S. 2006. The effect of boron (B) application on the growth and nutrient contents of maize in zinc $(\mathrm{Zn})$ deficient soils. Bulgarian Journal of Agricultural Science, 12: 387-392.

Diggs, C.A., Ratto, M.S., Shorrocks, V.M. 1992. Boron deficiency symptoms evaluation: the most accurate method to decide sunflower boron fertilization. In: 
The Proceedings of the $13^{\text {th }}$ International Sunflower Conference (Paisa, Italy, 8-10 September), pp., 1-7.

Gandhi, A.P., Jha, K., Gupta, V.C. 2008. Studies on the production of defatted sunflower meal with low polyphenol and phytate contents and its nutritional profile. ASEAN Food Journal, 15: 97-100.

Havlin, J.L., Tisdale, S.L., Beaton, J.D., Nalson, W.L. 2005. Soil Fertility and Fertilizers: An Introduction to Nutrient Management, pp. 275-277, $7^{\text {th }}$ edition, Dorling Kindersley (India) Pvt. Ltd., New Delhi, India.

Malakouti, M.J. 2007. Zinc is a neglected element in the life cycle of plants: A review. Middle East Russian Journal of Plant Science and Biotechnology, 1: 1-12.

MINFAL, 2011. Agricultural Statistics of Pakistan, Govt. of Pakistan, Ministry of Food, Agriculture and Livestock, Economic wing, Islamabad, Pakistan.

Oyinlola, E.Y. 2007. Effect of boron fertilizer on yield and oil content of three sunflower cultivars in the Nigerian savanna. Journal of Agronomy, 6: $421-426$.

Reddy, A.G.K., Chaturvedi, O.P. 2009. Effect of zinc, calcium and boron on growth and flowering in Gladiolus cv. Red Majesty. Crop Research, 38: 135-137.

Salim, M., Rahmatullah, G., Niazi, B.H. 1997.
Differential agronomic efficiency of two sunflower hybrids fertilized with three sulphur sources. Pakistan Journal of Soil Science, 13: 1-4.

Sarker, S.K., Chowdhury, M.A.H., Zakir H.M. 2002. Sulphur and boron fertilization on yield quality and nutrient uptake by Bangladesh soybean-4. Journal of Biological Sciences, 2: 729-733.

Sarkar, R.K., Anita, S., Chakraborty, A., Sah, A. 1999. Analysis of growth and productivity of sunflower (Halianthus annuus) in relation to crop geometry, nitrogen and sulphur. Indian Journal of Plant Physiology, 4: 28-31.

Tanaka, M., Fujiwara, T. 2008. Physiological roles and transport mechanism of boron: perspective from plants. European Journal of Physiology, 456: 671677.

Tariq, M., Mott, C.J.B. 2007. Effect of boron on the behavior of nutrients in soil-plant systems-A review. Asian Journal of Plant Science, 6: 195-202.

Tomar, T.S., Singh, S., Kumar, S., Tomar, S. 1997. Response of Indian mustard (Brassica juncea) to nitrogen, phosphorus and sulphur fertilization. Indian Journal of Agronomy, 42: 148-151.

Welch, R.M. 2003. Farming for nutritious foods: Agricultural technologies for improved human health. In: IFA-FAO Agriculture Conference: "Global Food Security and the Role of Sustainable Fertilization", (Rome, Italy, 26-28 March, 2003), pp., 1-26. 